DOI: https://doi.org/10.32836/2521-666X/2019-1-63-7

УДК 336:377

\author{
Тріпак М.M. \\ заслужений працівник освіти України, \\ кандидат економічних наук, доцент, \\ Подільський спеціальний навчально- \\ реабілітаційний \\ соціально-економічний коледж
}

\title{
Tripak Marian
}

Podilsky Special Educational and Rehabilitation

Socio-Economic College

\section{ЕКОНОМІЧНА СОЦІАЛІЗАЦІЯ МОРАЛЬНОСТІ В УМОВАХ СОЦАЛЬНО-ОСВІТНЬОЇ ІНКЛЮЗІї}

\section{ECONOMIC SOCIALIZATION OF MORALITY IN THE CONDITIONS OF SOCIAL AND EDUCATIONAL INCLUSION}

У статті розглянуто проблеми впливу моральності, духовних орієнтирів і світоглядних ідеалів на економічну життєдіяльність сочіуму, що стає не тільки актуальною науковою ідеєю, а й иентром гострої суспільної дискусї, спрямованої на пошуки балансу між ращіональністю, яка стрімко зростає в сучасному соиіумі, та мораллю як загальнолюдською цінністю, що має гармонізувати наше суспільство. Метою статті є визначення пріоритетності моральності, що виливає на економічну поведінку суб'єкта соиіуму в умовах соиіально-освітньої інклюзії в Україні. Проаналізовано різноманітні підходи до розуміння результату впливу моральності на економічну поведінку суб' єкта соиіуму в умовах інклюзії.

Ключові слова: інклюзивна освіта, суб'єкт соиіуму, моральність, мораль, економічна поведінка, сочіалізація, економічна соціалізація, економічна система, моральна економіка.

В статье рассмотрены проблемы влияния нравственности, духовных ориентиров и мировоззренческих идеалов на экономическую жизнедеятельность сочиума, что становится не только актуальной научной идеей, но и центром острой общественной дискуссии, направленной на поиски баланса между рациональностью, которая стремительно растет в современном сочиуме, и моралью как общечеловеческой ценностью, которая должна гармонизировать наше общество. Целью статьи является определение приоритетности нравственности, которая влияет на экономическое поведение субъекта сочиума в условиях сочиально-образовательной инклюзии в Украине. Проанализированы различные подходы к пониманию результата влияния нравственности на экономическое поведение субъекта сочиума в условиях инклюзии.

Ключевые слова: инклюзивное образование, субъект соииума, нравственность, мораль, экономическое поведение, сочиализаџия, экономическая сочиализащия, экономическая система, нравственная экономика. 
The article deals with the problems of the influence of morality, spiritual guidelines and ideological ideals on the economic activity of society, which become not only an actual scientific idea, but also a center of acute social discussion aimed at finding a balance between rationality, which is rapidly growing in the modern society, and morality as a universal human value that should harmonize our society. Also, in this article the problems of economic socialization of morality in the conditions of social and educational inclusion and in the modern Ukrainian educational space are considered, which are of particular importance, considering that the integration of persons with special needs in the socio-cultural and socio-economic environment of socialization is extremely relevant today. The article provides a comprehensive systemic monitoring of socio-economic inclusive socialization. The priority of inclusive socialization of the subject of a society with limited physical abilities in the economic system is determined. Represented economic model of economic socialization of morality in conditions of social and educational inclusion. Various approaches to understanding the result of moral education are analyzed, since the state of the Ukrainian economy depends primarily on the moral and professional incentive of the subject of society. The main factors influencing social rehabilitation of the society in economic morality under the conditions of social and educational inclusion are determined. The chronology of scientific materials concerning introduction of inclusive education, as well as economic socialization of morality in modern conditions has been worked out. The basic ways of realization of rehabilitation services are determined. Inclusive socialization in Ukraine under conditions of social and rehabilitation influence of the result of moral education and professional stimulus of the subject of society in the process of their interaction with the help of psychological and socio-economic mechanisms of socialization are considered. It is determined that socialization has the character and is carried out in the process of educational and preparatory activity in a special educational-rehabilitation inclusive institution. Different approaches to understanding the result of the influence of morality on the economic behavior of the subject of society under the conditions of inclusion are analyzed. The purpose of this article is to determine the priority of morality that affects the economic behavior of the subject of society in conditions of social and educational inclusion in Ukraine.

Keywords: inclusive education, subject of society, morality, morality, economic behavior, socialization, economic socialization, economic system, moral economy.

Постановка проблеми. Соціалізація розглядається як формування людини як суб'єкта соціуму, члена суспільства, суб'єкта культури, оволодіння соціально значущими цінностями, нормами, зразками поведінки; як процес накопичення суб'єктом життевого досвіду та соціальних установок, які відповідають його соціально-економічним функціям. Уважаємо, що в різних концепціях робляться акценти на ті чи інші боки процесу соціалізації, розглядаючи цей процес iз погляду філософії, культурології, соціології, психології, педагогіки та економіки. Однак загальним, на нашу думку, є те, що соціалізація здійснюється в процесі взаємодії суб'єктів за допомогою психологічних і соціально-економічних вищеназваних механізмів соціалізації. При цьому важливо підкреслити, що соціалізація має характер і здійснюється в процесі навчальної, ігрової, трудової, творчої та тренінгової діяльності. Але різноманітна діяльність передбачає певні способи контактів людей у соціумі, починаючи 3 найбільш простих, короткотермінових, формальних, поступово ускладнених у процесі більш тривалої предметної взаємодії (навчальних, ділових, виробничих, творчих) i закінчуючи найбільш складними - міжособистісними, моральними взаємовідносинами, тобто формування суб'єктів господарювання та соціально-економічної державності.

Процес соціалізації розглядається авторами 3 позиції двох підходів. Прихильники об’єктного підходу (Е. Дюркгейм, Т. Парсонс, Г. Террі Пейдж, Дж.Б. Томас, А.Р. Маршалл) уважають, що соціалізація - це процес освоєння дій очікуваної поведінки у відносинах сім’і та суспільства. При цьому пріоритетними $є$ цілі соціальної адаптації та пристосування до соціального середовища. Представники суб'єктного підходу (У.І. Томас, Ф. Знанецький, Ч.Х. Кулі, Дж.Г. Мід, Дж. Коулмен, І. Таллмен, У. Бронфенбреннер, I.C. Кон та ін.) акцентують увагу на активній, свідомій і творчій ролі людини у процесі соціалізації під час своїх взаємовідносин із навколишнім середовищем [1, с. 9]. Вплив моральності на економічну поведінку 
суб'єкта соціуму впроваджує у життя відповідні принципи та закони про права людей 3 інвалідністю та $є$ одним з основних елементів відкритого суспільства, спрямованого на подолання соціальної нерівності, який отримав назву «інклюзія». Тобто широкого спектру стратегій щодо забезпечення ресурсів, орієнтованих на підтримку груп населення або окремих громадян, які знаходяться у несприятливому становищі виключення 3 економічного, соціального, політичного, культурного життя суспільства.

У широкому сенсі це поняття розуміють як активний процес зміцнення відчуття належності особи або групи осіб, що, зрештою, перебувають під загрозою соціальної ізоляції. Розглядаючи питання соціального виключення, важливо визначити групи людей, які найчастіше опиняються у ситуації виключення 3 огляду на свою расову належність, соціальне та етнічне становище, віросповідання, стать та здібності, фізичні вади. Для подолання таких явищ у країні провідною стратегією політики є результат науково-практичного дослідження, де визначено, що економічно доцільним є здійснення інвестицій у людський капітал скрізь де це можливо замість прямого інвестування в соціальне обслуговування. Відповідно до цієї категорії, інклюзія розглядається як вигідний напрям соціального інвестування для майбутнього. Таким чином, питання соціальної інклюзії знаходять своє основне відбиття у сфері освітньої політики, оскільки освітня система є не тільки віддзеркаленням стану суспільства, а й важливим засобом його реформування. Досить часто інклюзія в освіті розглядається як підхід до навчання дітей та дорослих людей 3 особливими освітніми потребами в умовах системи вищої освіти. Отже, необхідне проведення низки заходів щодо впливу моральності на економічну поведінку суб'єкта соціуму в умовах соціально-освітньої інклюзії.

Аналіз останніх досліджень і публікацій. Вплив моральності на економічну поведінку суб' єкта соціуму в умовах соціально-освітньої інклюзії досліджували: Т. Боголіб, Є. Бойко, О. Василик, Т. Гребнєва, А. Гошко,
Г. Дмитренко, В. Журавський, I. Каленюк, П. Коваль, В. Князєв, С. Королюк, Т. Лев, Ю. Лисенко, О. Навроцький, В. Новіков, К. Павлюк, Ю. Палеха, Ж. Серкіс, В. Федосов, В. Шпотенко, М. Яструбський та ін. Наукові здобутки згаданих учених є значним внеском у теорію, методологію й організацію функціонування моральності в умовах інклюзивних процесів в Україні. Однак питання комплексного моніторингу моральності, що впливає на економічну поведінку суб'єкта соціуму в умовах соціально-освітньої інклюзії, розроблено ще недостатньо.

Незважаючи на важливість і актуальність інклюзивної освіти, науковці констатують серйозні проблеми в ії науковому розробленні та практичній реалізації. Дані обставини визначили актуальність теми дослідження та необхідність пошуку економіко-організаційних важелів впливу на активізацію розвитку інклюзивної освіти в Україні через механізм впливу моральності на економічну поведінку суб'єкта соціуму.

Мета статті полягає у визначенні пріоритетності моральності, що впливає на економічну поведінку суб'єкта соціуму в умовах соціально-освітньої інклюзії в Україні.

Виклад основного матеріалу. Досліджуючи внутрішні компоненти мотивації людини до економічної діяльності, які включають у себе певні моральні цінності, А. Маршалл, зокрема, говорив про те, що в господарській діяльності, як і всюди, людина піддається впливу особистих схильностей, уявлень про обов'язок і відданість високим ідеалам. Їй властиві марнославство й безтурботність, почуття насолоди самим процесом гарного виконання справи, готовність принести себе в жертву заради родини. Усі ці якості і моральні цінності формуються й детермінуються в людині саме в умовах економічної діяльності. На думку А. Маршалла, тільки за допомогою економічної діяльності людина здатна досягти задоволення всіх своїх індивідуальних потреб, водночас задовольняючи потреби інших [2].

Отже, розглядаючи історико-філософський аспект понять «моральність», «мораль», 
ми звернули увагу на те, що давньогрецькі філософи античного ідеалізму Платон, Сократ та ін. тісно пов'язували мораль із вселенським світопорядком [8]. Інші філософи звертали увагу на залежність моральності від формування суспільства і політики. «Людина $\epsilon$ моральна істота тільки тому, що вона політична істота», - писав Аристотель [9]. Для епохи Середньовіччя характерне розуміння моралі як принципу божественного авторитету, системи заповідей, які йдуть від Всевишнього, а моральна діяльність полягала в служінні Йому. Згідно з ученням про категоричний імператив I. Канта (XVIII ст.), незмінний постулат, моральність тлумачиться як вічна і незмінна категорія, незалежна від суспільства й суспільних відносин. Моральність при цьому є продуктом вищого духовного стану людини і має божественне походження. Моральні вимоги виступають як повеління Всевишнього [3]. У XVIII ст. пролонгували постулат Е.Е. Купера, А. Сміта, Д. Юма, який називається «етичним сентименталізмом» і в якому стверджувалося, що основою моралі $\epsilon$ моральні почуття [4]. За твердженням німецького філософа XIX ст. Гегеля, саме почуття лежать в основі моральності. Мислитель уважав, що словесне навчання моралі $є$ безплідним. Справжня моральність - продукт самовиховання, який опирається на почуття радості і краси буття [10].

Німецький філософ XIX ст. Л. Фейєрбах уважав любов вищим проявом морального почуття, яке приносить щастя. Моральні почуття людини, на думку Л. Фейєрбаха, - це $\epsilon$ його природне надбання, його родова сутність. Він розглядав моральний зміст людини як натуральний продукт спілкування людини 3 ближніми, прагнення бути коханими та любити [11]. Проте філософи XX ст. С.Л. Франк, К.С. Льюїс, Д. Бонхьофер уважали турботу про потреби конкретних людей, служіння іншим, існування для інших найбільш важливими для моральності людини [5]. Проведений аналіз поглядів філософів на розуміння суті вказаних наукових категорій показав, що існують різні думки про співвідношення понять «моральність» $\mathrm{i}$ «мораль».
Ураховуючи вищезазначені постулати, можна припустити, що у філософії мораль і моральність розглядаються в двох аспектах: як сфера почуттів, волі чи розуму, які $\epsilon$ проявом внутрішнього світу людини (божественного промислу, світового розуму) i виражаються в поняттях добра і зла, оціночному відношенні до світу; як вираження того чи іншого способу соціальної поведінки, яка проявляється у вчинках, звичаях, вдачі і визначається суспільно-політичними чинниками.

Однак $\epsilon$ й інша точка зору. Так, Г. Гегель (XIX ст.) першим указав на двояке розуміння моралі і позначив ї двома термінами - «мораль» і «моральність». Мораль у розумінні Гегеля - це результат життя сучасного суспільства. Моральність - характеристика об'єктивної поведінки людей [10].

Як зазначалося вище, суспільство разом 3 іншими чинниками має значний вплив на зміст понять «мораль» і «моральність», що, своєю чергою, впливає на характер взаємовідносин особистості з оточуючими людьми. Моральні норми, моральні цінності виступають орієнтирами у вибудовуванні взаємовідносин особистості 3 навколишнім світом, соціумом. При цьому варто відзначити, що для людини моральні цінності здатні стати особистісно значущими тільки в процесі соціалізації і в процесі формування його взаємозв'язку із соціумом.

На основі порівняльного аналізу понять «моральність» і «мораль» можна зробити висновок про те, що мораль - це система вироблених у суспільстві норм, правил та вимог, що регулюють взаємодію між людьми, ix відношення до явищ реального світу. Моральність тлумачиться як сукупність свідомості, навичок і звичок людини, які пов'язані $з$ дотриманням цих норм, правил та вимог. Моральність на відміну від моралі являє собою складне соціально-психологічне утворення. Моральність конкретної людини - це освоєна внутрішньо прийнята суспільна мораль, яка регулює іiі індивідуальну поведінку на основі світоглядних переконань і почуття совісті. На нашу думку, таке 
розуміння моральності слугуватиме утвердженню суб'єктів державності і формуванню економічного підгрунтя індивідуумів для створення доданої вартості. Отже, у результаті аналізу сутності поняття «моральність» встановлено іiі приналежність до особистісних характеристик. Особливо значущим для нашого дослідження $є$ те, що моральність формується разом 3 особистістю суб'єкта соціуму та невіддільна від його «Я». Тому в економічній системі моральність розглядаємо як одне з базових понять морального виховання суб'єкта соціуму - державотворця та суб'єкта господарювання. Приступаючи до розгляду морального виховання суб'єкта соціуму, доцільно виділити його характерну особливість, яка полягає у тому, що зміст морального виховання не $є$ статичним. Ці зміни пов'язані з переоцінкою провідних цінностей, моральних та законодавчих установок у суспільстві, зі змінами цілей загальнодержавного морального виховання і уявлень про його результати. У результаті проведеного моніторингу виявлено чинники впливу на формування змісту морального виховання суб'єкта соціуму в процесі взаємовідносин унаслідок створення валового внутрішнього продукту та доданої вартості в країні:

- зміни світової основи та ціннісних орієнтацій суспільства, які здійснюють суттєвий вплив на розуміння джерела, змісту, мети і результату процесу морального виховання i підготовку професійного суб' єкта соціуму;

- формування різних підходів до розуміння сутності освіти та зміни уявлень про роль особистості у цьому процесі;

- активний розвиток психології особистості, розроблення концепцій щодо виявлення структури й економіко-психологічного механізму процесу морального виховання;

- практичний досвід морального виховання студентів в умовах інклюзивної вищої освіти.

Отже, перш ніж перейти до питань, пов'язаних із вихованням моральних взаємовідносин студентів та інших суб'єктів соціуму в інклюзивній освіті, проаналізуємо різноманітні підходи до розуміння результату морального виховання. Дослідження наукової літератури показало, що науковці багатогранно представляють сутність результату морального виховання.

Незважаючи на той факт що зміст понять «мораль» і «моральність» загальновідомий, зупинимося на їх інтерпретації. На основі лінгвістичного аналізу слів «моральність» i «мораль» можна зробити такий висновок: по-перше, у найвідоміших словниках ці слова розглядаються як синоніми; по-друге, мораль та моральність виражають, з одного боку, прийняті в суспільстві правила та звичаї, з іншого - особистісні особливості людини; по-третє, структуру лексичного значення слова «моральність» становлять такі контенти: душа, дух; моральні спонукання; норми і правила; вдача, характер, поведінка, звичка тощо.

Отже, економічна система має службовий характер, вона необхідна для забезпечення тимчасового земного існування суб'єкта соціуму, а ії стан, як, утім, і стан інших сфер життя людини, визначається моральним станом суспільства, тобто залежить від виконання духовно-морального закону.

Економічна поведінка людини, передусім, визначається іiі моральними якостями. А. Рих наполягає на тому, що питання про суть господарювання повинне знаходитися у сфері етики, а не економіки. Якщо економіка не служить користі суспільства, вона стає абсурдною, незважаючи на зростаючі прибутки і досягнення нею вершин раціональності. У своїх оцінках А. Рих керується неекономічними критеріями. Людина дістає можливості використання природних ресурсів у різних сферах своєї діяльності й у цьому сенсі отримує право господаря на планеті, але при цьому іiі рішення про використання матеріальних ресурсів повинні обмежуватися іiі внутрішньою відповідальністю перед Всевишнім [6].

Дуже цікаві, вірні й досить переконливі докази визначального впливу моральності, духовно-морального закону на економіку наводить відомий сербський богослов, громадський діяч і вчений (доктор філософії та 
богослов'я) святитель Микола Сербський (1881-1956). Зупинимося на сутності духовно-морального закону. Духовно-моральний закон відноситься до кожної людини. Цей закон полягає у необхідності життя відповідно до совісті, заповідей. У християнстві дві найвищі заповіді полягають у любові до Всевишнього і ближнього. Виконання або порушення цих правил впливає на долю людини і людства у цілому. При цьому мається на увазі як земні наслідки праведного або неправедного життя, так і долі людини у вічності. Так, згідно з ученням релігійної літератури деяких східних вірувань, природні катаклізми, війни, хвороби, у тому числі невиліковні, зниження народжуваності, загибель міст і цивілізацій - прямий наслідок порушення морального закону. Такі наслідки порушення цього закону не заперечуються і християнством. Але у найдосконалішому духовно-моральному законі, даному Новим Завітом, акценти зміщуються не на земні наслідки поведінки людини, а на рішення долі людини у вічності. Хоча людство, що забулося, і зараз спостерігає зовнішні ознаки духовно-моральної кризи: деградацію моральності, демографічну, екологічну, економічну кризи тощо [7]. У цілому завдання його дослідження набагато ширше, ніж доказ впливу духовно-морального закону тільки на економіку. Він стверджує і доводить це, досліджуючи Священну історію Старого Завіту, що духовно-моральний закон визначає дію так званих природних законів, хід історії, долі народів, дію соціальних законів [7, с. 31].

Отже, економіка і моральність - це взаємозумовленість моральних принципів і норм із різними елементами економічної системи на всіх етапах розвитку суспільства. На нижчій стадії розвитку, коли переважали приватнокапіталістична власність та механізм ринкового саморегулювання, домінували егоїстичні інтереси капіталістів, спрямовані на якнайшвидше збагачення шляхом жорстокої експлуатації найманої праці. За сучасних умов ці ідеї проповідують представники неокласичного напряму економічної теорії, передусім неоконсерватори. Вони дотриму- ються, зокрема, ідеї ринкової моралі, в якій взаємодія окремого індивіда або сім'ї із суспільством та компаніями і фірмами, а також у межах окремої сім’ї здійснюється шляхом укладання контрактів та угод. Така ідеологія грунтується на необмежених можливостях ринкового механізму саморегулювання й значною мірою ігнорує численні глибокі вади ринкової економіки. Ці ідеї за сучасних умов не здатні консолідувати і сформувати цілісну національну економічну систему, національну ідентичність народу, підривають принципи та цінності християнської економіки, а ядром господарського механізму стало державне регулювання економіки, яке доповнюється наднаціональним, певною мірою долається егоїзм приватних капіталістів, а отже, соціалдарвіністська мораль ринкового механізму.

Висновки. Економічна соціалізація моральності в умовах соціально-освітньої інклюзії - це процес апробації суб'єкта соціуму з обмеженими потребами в економічну сферу суспільства, формування у нього економічного мислення, практичних навиків та професіоналізму; процес інтеріоризації нової реальності, що включає пізнання економічної дійсності; засвоєння економічних знань, набуття навичок економічної поведінки та прагматичних дій будування державності і патріотизму.

Для створення етичного середовища в економіці України зараз визначальну роль підіграють особистісні чинники: професійна компетентність і висока моральність політиків, керівників і бізнесменів. В умовах недосконалого законодавства і системи контролю, 3 одного боку, і ментальної особливості нашого народу не виконувати юридичні норми і приписи, але керуватися, передусім, природним правом «суди по совісті, а не згідно із законом», усними домовленостями, заснованими на довірі, й неформальними правилами - 3 іншого, найважливіше визначальне значення має приклад поведінки політиків, керівників, що формує довіру або недовіру до влади і моделює поведінку більшості членів суспільства, у тому числі в економічній сфері. Стан 
економіки України передусім залежить від морального капіталу керівників, політиків, бізнесменів. Другий, такий же за значимістю для створення морального капіталу чинник, розроблення й упровадження в програми підготовки та перепідготовки бакалаврів, фахів- ців і магістрів відповідних учбових курсів i програм. Зміст і методика їх викладання мають бути такими, щоб, прослухавши їх, випускники мали моральні переконання, які б спрямовували їх професійні знання на благо суспільства, а не на шкоду йому.

\section{Список використаних джерел:}

1. Мудрик А.В. Соціалізації людини : навчальний посібник. Київ : Центр навчальної літератури, 2004. $304 \mathrm{c}$.

2. Маршалл А. Принципи економічної науки. УМК Центр, 2001. 216 с.

3. Кант И. Лекции по этике. Москва. Республик, 2000. 146 с.

4. Смит А. Теория нравственных чувств. Республика, 1997. 279 с.

5. Франк С. Духовные основы общества. Республика,1992. 512 с.

6. Рих А. Хозяйственная этика. Москва. Посев, 1996. 810 с.

7. Сербский Н. Слово о Законе (Номология). Издательство Братства Святителя Алексия. Центр святоотеческих переводов. Издательство «Феофания», 2005. 128 с.

8. Платон. Собрание сочинений : в 4-х т. Т. 1. Москва. Мысль, 1990. 860 с.

9. Асмус В. Аристотель. Сочинения : в 4-х т. Т. 1. Москва. Мысль, 1976. 550 с.

10. Гегель Г. Энциклопедия философских наук : в 3-х т. Т. 1. Москва. Мысль, 1974. 452 с.

11. Фейеберх Л. История философии. Собрание произведений : в 3-х т. Т. 1. Москва. Мысль, 1974. 544 с. 